\author{
A.R. Yeshkeyev* \\ Karagandy University of the name of academician E.A. Buketov, Karaganda, Kazakhstan
}

(E-mail: aibat.kz@gmail.com)

\title{
On Jonsson varieties and quasivarieties
}

\begin{abstract}
In this paper, new objects of research are identified, both from the standpoint of model theory and from the standpoint of universal algebra. Particularly, the Jonsson spectra of the Jonsson varieties and the Jonsson quasivarieties are considered. Basic concepts of 3 types of convexity are given: locally convex theory, $\varphi(x)$-convex theory, $J-\varphi(x)$-convex theory. Also, the inner and outer worlds of the model of the class of theories are considered. The main result is connected with the question of W. Forrest, which is related to the existential closedness of an algebraically closed variety. This article gives a sufficient condition for a positive answer to this question.
\end{abstract}

Keywords: Jonsson theory, semantic model, Jonsson spectrum, Jonsson variety, Jonsson quasivariety.

This article is related to the new concepts of Jonsson varieties and quasivarieties. The interest in such classes of structures lies in the fact that today the study of Jonsson theories are related exclusively to the problems of the classical model theory and some of its modern sections. However, it seems to us, the use of the concepts of varieties and quasivarieties will expand the area of application of the apparatus of Jonsson theories and, accordingly, the content of the results on the study of Jonsson theories also within the framework of universal algebra. Moreover, the well-known, already classical results on the description of model-theoretic questions, both varieties, and quasivarieties, can be considered from the standpoint of studying Jonsson's theories.

We give well-known definitions and results related to the description of various classes of varieties and quasivarieties.

If an axiomatizable class $K$ is closed concerning subsystems, from it is called universal, if it is closed for homomorphic images, then it is called positive, and if it is closed to filtered products, then it is called Horn. We will call a theory $T$ universal, positive, or Horn if it has a system of axioms consisting, respectively, of universal, positive, or Horn sentences.

The following theorem can already be related to the classical Model Theory.

Theorem 1. (Tarski, Lyndon, Keisler) [1; 351]. Let $K$ be some axiomatizable class of algebraic systems. Then:

a) $K$ is a universal if and only if the theory $T h(K)$ is universal;

b) $K$ is positive if and only if the theory $T h(K)$ is positive;

c) $K$ is Horn if and only if the theory $T h(K)$ is Horn.

In what follows, the class of systems, if the context does not imply otherwise, we will understand the "axiomatizable class of systems".

Most of the classes of systems considered in algebra have some of the listed closedness properties. If the class $K$ is a positive Horn universal, then $K$ is called a variety. Examples of varieties are the classes of all semigroups, all groups, Abelian groups, Boolean rings, nilpotent groups of steps $\leq s$. Universal Horn classes are called quasivarieties. Quasivarieties are, for example, the class of torsion-free groups from any variety of groups and the class of rings of characteristic 0. An example of a positive Horn class that is neither positive nor universal is the class of atomless Boolean algebras.

Thus, we can formulate the well-known classical result:

Theorem 2. (Birkhoff) [2; 237] For a non-empty class $K$ of algebraic systems to be a variety, it is necessary and sufficient that the following conditions are satisfied:

1 ) the Cartesian product of an arbitrary sequence of $K$-systems is a $K$-system;

2 ) any subsystem of an arbitrary $K$-system is a $K$-system;

${ }^{*}$ Corresponding author.

E-mail: aibat.kz@gmail.com 
3) any homomorphic image of an arbitrary $K$-system is a $K$-system;

i.e. it is necessary and sufficient that the class $K$ be hereditary, multiplicatively, and homomorphically closed.

From this, we see, for example, that groups do not form varieties in signature with one multiplication; fields do not form varieties in the ring signature, and so on.

In the well-known monograph of A.I. Maltsev [2], one can find the following definitions of varieties and quasivarieties.

Varieties and quasivarieties of algebras are classes of algebras that can be specified using a collection of identities or, respectively, quasi-identities (conditional identities). Since identities and quasi-identities are $\forall$ formulas, varieties, and quasivarieties are particular types of universally axiomatizable classes of algebras.

Now, we define what the unit structure means.

For each signature $\Omega$ there is a unique (up to isomorphism) unit system $\mathfrak{U}_{e}$ consisting of only one element $e$ for which

$$
F(e, \ldots e)=e, P(e, \ldots, e)=\mathrm{T}(F, P \in \Omega) .
$$

Definition 1. [2] A subclass $M$ of algebraic systems of signature $\sigma$ of some class $K$ is called hereditary in $K$ if each $K$-subsystem of an arbitrary $M$-system is an $M$-system.

Theorem 3. [2; 271]. For the class of systems $R$ to be a quasivariety, it is necessary and sufficient that the class $R$ is:

1) locally closed;

2) multiplicatively closed;

3) contained a unitary system.

Consequence 1. [2;272] The class of systems $R$ is a quasivariety if and only if $R$ is

1) closed with respect to filtered products;

2) a hereditary;

3) contained a unitary system.

In [3-4], the question was raised about study of the class of Jonsson theories of a certain fixed class of structures concerning the concept of cosemanticness, which is an equivalence relation. Such classes of Jonsson theories form the Jonsson spectrum of a fixed class of structures of arbitrary signature. The main idea of this article is to study the Jonsson spectra of such classes of structures that are varieties or quasivarieties, the theory of whose classes is Jonsonian. On the one hand, this approach is new and naturally generalizes all higher formulations of problems; on the other hand, it narrows the class of varieties or quasivarieties with the additional condition of joint embedding and amalgam.

Let us give the following definitions.

Let $K$ be the class of structures of countable signature $\sigma$. Let's introduce the notation:

$$
\forall \exists(K)=T h(K) \cup\{\varphi \mid \varphi \text { is a } \forall \exists \text {-sentence and } \varphi \cup T h(K) \text { is a consistent }\} .
$$

Definition 2. We call a $K$ Jonsson variety if:

1) $K$ is a variety in the usual sense [2; 269];

2) $\forall \exists(K)$ is a Jonsson theory.

Definition 3. We call a $K$ Jonsson quasivariety if:

1) $K$ is a quasivariety in the usual sense $[2 ; 269]$;

2) $\forall \exists(K)$ is a Jonsson theory.

Consider the $J \operatorname{SpV}(K)$ be Jonsson spectrum of the Jonsson varieties of class $K$, where $K$ is the Jonsson variety:

$$
J \operatorname{SpV}(K)=\left\{T / T \text { is a Jonsson theory, } T=T h_{\forall \exists}(N), N \subseteq K, N \text { is a subvariety of } K\right\} .
$$

Consider the $J \operatorname{SpQV}(K)$ be Jonsson spectrum of the Jonsson quasivarieties of the class $K$, where $K$ is the Jonsson quasivariety:

$$
J \operatorname{SpQV}(K)=\left\{T / T \text { is a Jonsson theory, } T=T h_{\forall \exists}(N), N \subseteq K, N \text { is a subquasivariety of } K\right\} .
$$

Then $\operatorname{JSp} Q V(K) / \bowtie$ is denoting the factor set of the Jonsson spectrum of Jonsson quasivariety of the class $K$ by the relation $\bowtie$.

It is clear that $J \operatorname{SpQV}(K) \subseteq J \operatorname{Sp}(\mathcal{A})$ for any model $\mathcal{A} \in K$, where $J \operatorname{Sp}(\mathcal{A})$ is the Jonsson spectrum [3-4] of the model $A$. 
We say that class $K_{1} J S p Q V$-cosemantic to class $K_{2}\left(K_{1} \underset{J S p Q V}{\bowtie} K_{2}\right)$ if $J S p Q V\left(K_{1}\right) / \bowtie=J S p Q V\left(K_{2}\right) / \bowtie$.

Theorem 4. Let $[T] \in J \operatorname{SpV}(K) . K$ is a Jonsson variety of abelian groups, then $C_{[T]} \in E_{[T]}$ its semantic model of the center $[T]^{*}$, and $C_{[T]}$ be a divisible group and its standard Shmelev group is representable in the form $\oplus_{p} \mathbb{Z}_{p^{\infty}}^{\left(\alpha_{p}\right)} \oplus \mathbb{Q}^{(\beta)}$, where $\alpha_{p}, \beta \in \omega^{+}, 2^{\omega}=\left|C_{[T]}\right|$.

We call the pair $\left(\alpha_{p}, \beta\right)_{C_{[T]}}^{A}$ the Jonsson invariant of the abelian group $A$ if the standard group of the Shmelian group $A$ is representable as $\oplus_{p} \mathbb{Z}_{p \infty}^{\left(\alpha_{p}\right)} \oplus \mathbb{Q}^{(\beta)}$, where $C_{[T]}$ is semantic model of $[T] \in J \operatorname{Sp} V(A) / \bowtie$.

Let $K$ be the class of Jonsson variety of abelian groups. We define the following set $\left\{\left(\alpha_{p}, \beta\right)_{C_{[T]}}^{K}:[T] \in\right.$ $J S p V(K) / \bowtie$, for all prime $p\}$ as the Jonsson invariant of the factor-set of Jonsson variety $J S p V(K) / \bowtie$ and denote it by $\operatorname{Jnv}(J \operatorname{Sp} V(K) / \bowtie)$.

Let's introduce the notation: $\mathbb{C}_{K}=\left\{C_{[T]} \mid[T] \in J S p V(K)\right\}$.

Theorem 5. Let $K_{1}$ and $K_{2}$ be an arbitrary classes of Jonsson variety of abelian groups, then the following conditions are equivalent:

1) $K_{1} \underset{J S p V}{\bowtie} K_{2}$

2) $\operatorname{JInv}\left(J \operatorname{Sp} V\left(K_{1}\right) / \bowtie\right)=J \operatorname{Inv}\left(J \operatorname{Sp} V\left(K_{2}\right) / \bowtie\right)$.

Proof. The proof follows from the above definitions and from the theorem [5].

Let $c l$ be the closure operator of some pregeometry defined on all subsets of semantic model of considered Jonsson theory.

Let $[T] \in J \operatorname{SpQV}(\mathcal{A}) / \bowtie$. The center of Jonsson class $[T]$ will be called an elementary theory $[T]^{*}$ of its semantic model $\mathcal{C}_{[T]}$, i. e. $[T]^{*}=\operatorname{Th}\left(\mathcal{C}_{[T]}\right)$ and $[T]^{*}=\operatorname{Th}\left(\mathcal{C}_{\Delta}\right)$ for every $\Delta \in[T]$.

Denote by $E_{[T]}=\bigcup_{\Delta \in[T]} E_{\Delta}$ the class of all existentially closed models of the class $[T] \in J \operatorname{SpQV}(\mathcal{A}) / \bowtie$. Note that $\bigcap_{\Delta \in[T]} E_{\Delta} \neq \varnothing$, since at least for every $\Delta \in[T]$ we have $\mathcal{C}_{[T]} \in E_{\Delta}$.

Let $\mathcal{A}, \mathcal{B} \in K$, where $K$ is a variety (a quasivariety).

Definition 4. We say that a model $\mathcal{A}$ is $J S p V$-cosemantic to a model $\mathcal{B}(\mathcal{A} \underset{J S p V}{\bowtie} \mathcal{B})$ if $J S p V(\mathcal{A}) / \bowtie=$ $J S p V(\mathcal{B}) / \bowtie$. Accordingly, we say that a model $\mathcal{A}$ is $J S p V$-cosemantic to a model $\mathcal{B}$ regarding $\Gamma$, where $\Gamma \subseteq L$ and write it $\mathcal{A} \underset{J S p V}{\Gamma} \mathcal{B}$ if $J \operatorname{Sp} V_{\Gamma}(\mathcal{A}) / \bowtie=J S p V_{\Gamma}(\mathcal{B}) / \bowtie$

Definition 5. We say that a model $\mathcal{A}$ is $J S p Q V$-cosemantic to a model $\mathcal{B}(\mathcal{A} \underset{J \operatorname{SpQV} V}{凶} \mathcal{B})$ if $J \operatorname{SpQV}(\mathcal{A}) / \bowtie=$ $J \operatorname{SpQV}(\mathcal{B}) / \bowtie$. Accordingly, we say that a model $\mathcal{A}$ is $J \operatorname{Sp} Q V$-cosemantic to a model $\mathcal{B}$ regarding $\Gamma$, where $\Gamma \subseteq L$ and write it $\mathcal{A} \underset{J S p Q V}{\Gamma} \mathcal{B}$ if $J \operatorname{SpQ} V_{\Gamma}(\mathcal{A}) / \bowtie=J S p Q V_{\Gamma}(\mathcal{B}) / \bowtie$.

Definition 6. The class $[T] \in J \operatorname{SpQV}(\mathcal{K}) / \bowtie$ is called elementarily closed regarding to $K$, if $\forall[T]^{\prime} \in$ $J \operatorname{SpQV}(\mathcal{K}) / \bowtie:[T]^{\prime} \neq[T] \Rightarrow E_{[T]} \cap E_{[T]^{\prime}}=\emptyset$.

Definition 7 . The class $[T] \in J S p Q V(\mathcal{K}) / \bowtie$ is called locally convex regarding to $K$, if $T h_{\forall \exists}\left(\bigcap E_{\Delta}\right)$ is a Jonsson theory and reflexcially convex if $T h_{\forall \exists}(K) \in J \operatorname{SpQV}(\mathcal{K})$.

Definition 8. The class $[T] \in J \operatorname{Sp} Q V(\mathcal{K}) / \bowtie$ is called companion-convex regarding to $K$ if the theory $\nabla=$ $T h_{\forall \exists}\left(\bigcap E_{\Delta}\right)$ is a Jonsson theory and has a model companion.

We can define the completeness of the class $[T]$ regarding Jonsson variety $K$ (Jonsson quasivariety $K$ ) as follows (Definition 7), and all four types of completeness are independent of each other and can combine. An interesting problem is the transfer of results from the Jonsson spectrum to the Jonsson variety (Jonsson quasivariety), when the completeness of the Jonsson theory is replaced by the following types of completeness and their combinations.

Let $[T] \in J \operatorname{Sp} V(K)([T] \in J S p Q V(K)), \Gamma \subseteq L$.

Definition 9. The class $[T]$ is called a $\Gamma_{i}$-complete class regarding to $K$, if the following $i$-conditions are true:

$\left.i_{1}\right) \forall \mathcal{A}, \mathcal{B} \in E_{[T]}, \mathcal{A} \underset{J S p V}{\stackrel{\Gamma}{\infty}} \mathcal{B}(\mathcal{A} \underset{J S p Q V}{\Gamma} \mathcal{\perp})$

$\left.i_{2}\right) \forall \mathcal{A}, \mathcal{B} \in E_{[T]}, \mathcal{A} \underset{J S p V}{\stackrel{\Gamma}{\infty}} \mathcal{B}(\mathcal{A} \underset{J S p Q V}{\stackrel{\Gamma}{\infty}} \mathcal{B})$ and $\forall \Delta \in[T], \Delta-\Gamma$-complete;

$\left.i_{3}\right) \forall \varphi \in \Gamma, \forall \Delta \in[T], \Delta \vdash \varphi$ or $\Delta \vdash \neg \varphi \Leftrightarrow \forall \mathcal{A}, \mathcal{B} \in \operatorname{Mod} \Delta, \forall \Delta \in[T], \mathcal{A} \equiv_{\Gamma} \mathcal{B}$;

$\left.i_{4}\right) \forall \varphi \in \Gamma, \forall \mathcal{A}, \mathcal{B} \in E_{[T]}, \mathcal{A} \models \varphi \Leftrightarrow \mathcal{B} \models \varphi$. 
The concepts of completeness and model completeness do not coincide, but as shown by [6], in the case of a perfect Jonsson theory, these concepts coincide for the Jonsson theory under consideration. Therefore, in going over to the problem of the Jonsson spectrum, we must take into account that in the case of an imperfect class, these concepts do not coincide.

A Jonsson variety $K$ (a Jonsson quasivariety $K$ ) will satisfy some model-theoretic notion $P$ if each class $[T] \in J \operatorname{Sp} V(K)([T] \in J \operatorname{Sp} Q V(K))$ satisfies the $P$ property. Next, we define some particular cases of the property $P$ for the Jonsson variety $K$ (the Jonsson quasivariety $K$ ) through an arbitrary class $[T] \in J S p V(K)$ $([T] \in J \operatorname{SpQV}(K))$ :

Definition 10. The class $[T]$ is model complete if and only if $\forall \Delta \in[T], \Delta$ is model complete.

A Jonsson variety $K$ (a Jonsson quasivariety $K$ ) is model complete, if any class $[T] \in J S p V(K)([T] \in$ $J \operatorname{Sp} Q V(K))$ is model complete if and only if $\forall \mathcal{A}, \mathcal{B} \in E_{[T]}, \forall$ monomorphism $f: \mathcal{A} \rightarrow \mathcal{B}$ is elementary if and only if $\forall \varphi \in L, \exists \psi \in \forall \cap \exists:[T] \vdash(\varphi \sim \psi)[T] \vdash(\varphi \sim \psi) \leftrightharpoons \forall \Delta \in[T], \Delta \vdash(\varphi \sim \psi)$.

Lemma 1. If $\Delta \in[T]$ and $\Delta$ is imperfect, then $\exists \mathcal{B} \in E_{\Delta}, \mathcal{B} \in E_{\Delta^{\prime}}$ for some $\Delta^{\prime} \in[T]$.

Definition 11. Two Jonsson variety (Jonsson quasyvariety) $K_{1}, K_{2}$ existentially mutually model complete to each other $\left(K_{1} \leftrightarrow K_{2}\right)$, if for any $[T]_{1} \in K_{1},[T]_{2} \in K_{2}$ follows that the classes $[T]_{1},[T]_{2}$ existentially mutually model complete to each other $\left([T]_{1} \leftrightarrow[T]_{2}\right)$, i.e. $\forall \mathcal{B} \in E_{[T]_{1}}, \exists \mathcal{B}^{\prime} \in E_{[T]_{2}}: \mathcal{B} \cong \mathcal{B}^{\prime}$ and the converse is true.

Lemma 2. $K_{1} \leftrightarrow K_{2} \Leftrightarrow T h_{\forall}\left(K_{1}\right)=T h_{\forall}\left(K_{2}\right)$.

Let us consider some properties of the Jonsson spectrum at fixed completeness (a special case of Definition $\left.9\left(i_{2}\right)\right)$.

Let $K$ be a Jonsson variety (a Jonsson qvazyvariety).

$[T] \in J \operatorname{SpV}(K)([T] \in J \operatorname{SpQV}(K))$.

$\operatorname{Mod}[T]=\left\{\mathcal{A} \in \operatorname{Mod} \sigma_{K} / \mathcal{A} \models T_{i}, \forall T_{i} \in[T]\right\}$.

$\operatorname{Mod}(\operatorname{JSp} V(\mathcal{A}))=\left\{\mathcal{B} \in \operatorname{Mod} \sigma_{K} / \mathcal{B}=T_{j}, \forall T_{j} \in \operatorname{JSpV}(\mathcal{A})\right\}\left(\operatorname{Mod}(\operatorname{JSp} Q V(\mathcal{A}))=\left\{\mathcal{B} \in \operatorname{Mod} \sigma_{K} / \mathcal{B} \models\right.\right.$ $\left.\left.T_{j}, \forall T_{j} \in J \operatorname{SpQV}(\mathcal{A})\right\}\right)$.

$\operatorname{Mod}(\operatorname{JSp} V(\mathcal{A}) / \bowtie)=\left\{\mathcal{B} \in \operatorname{Mod} \sigma_{K} / \mathcal{B}=[T], \forall[T] \in J \operatorname{SpV}(\mathcal{A}) / \bowtie\right\}\left(\operatorname{Mod}(\operatorname{JSp} Q V(\mathcal{A}) / \bowtie)=\left\{\mathcal{B} \in M o d \sigma_{K} / \mathcal{B} \models\right.\right.$ $[T], \forall[T] \in J \operatorname{SpQV}(\mathcal{A}) / \bowtie\})$.

From above definitions, we can conclude the fact about elementarity: the $E_{[T]}$ is elementary class if and only if $[T]$ has a model companion.

Definition 12. $[T]$ has a model companion if any $E_{T_{i}}$ will be an elementary class, $T_{i} \in[T]$.

Lemma 3. $K_{1} \underset{J S p Q V}{\bowtie} K_{2} \Leftrightarrow J S p Q V(\mathcal{A}) / \bowtie=J S p Q V(\mathcal{B}) / \bowtie, \forall \mathcal{A} \in E_{K_{1}}, \forall \mathcal{B} \in E_{K_{2}}$.

Proof. The proof follows from Definitions 10-12.

$J \operatorname{SpV}(K)(J \operatorname{Sp} Q V(K))$ is a perfect, i.e. for any $[T] \in J \operatorname{SpV}(K)([T] \in J \operatorname{SpQ} V(K))$ is true that the $[T]$ is perfect iff $C_{[T]}$ is saturated.

Let $J S p V(K)(J S p Q V(K))$ be a perfect, then for any $[T] \in J S p V(K)([T] \in J S p Q V(K))$ the following conditions hold:

1) $[T]$ is complete iff $\forall \mathcal{A}, \mathcal{B} \in E_{[T]}, \mathcal{A} \underset{J S p}{\bowtie} \mathcal{B}$.

2) $E_{[T]}=\bigcup_{i \in I} E_{T_{i}}$.

3) The $[T]$ is $\forall \exists$-complete if and only if $\forall \mathcal{A}, \mathcal{B} \in E_{[T]}, \mathcal{A} \underset{J S p}{\stackrel{\forall}{凶}} \mathcal{B}$.

4) $A \underset{J S p}{\forall \ni} \mathcal{B}$ iff $J S p Q V_{\forall \exists}(\mathcal{A}) / \bowtie$ iff $J S p Q V_{\forall \exists}(\mathcal{B}) / \bowtie$.

5) $J \operatorname{SpQ} V_{\forall \exists}(\mathcal{A}) / \bowtie=\{T \mid T$ is $\forall \exists$-complete Jonsson theory, $\mathcal{A} \models T\}$.

Definition 13. The class of the theory $[T]$ called existential prime, if:

1) it has a prime algebraic model and the class of all algebraically prime models; it is denoted by $A P$,

2) the class $\left(E_{[T]}\right)$ of theory $[T]$ has non-empty intersection with an $A P$ class, i.e., $[T]_{A P} \cap E_{[T]} \neq \emptyset$.

Definition 14. A set $X$ is called a theoretical set, if $X$ is Jonsson set, $\varphi(C)=X$ and the sentence $\forall \bar{x} \exists \bar{y} \psi(\bar{x}, \bar{y})$ defines some Jonsson theory.

A class $[T] \in J S p(M) / \bowtie$ is called $J-\varphi(x)$-convex if all theories from class $[T]$ are $J-\varphi(x)$-convex.

Definition 15. The class $[T]$ will be called $\varphi(x)$-convex if it is strong convex in the classical sense [1] and for any existentially closed model $N_{i}$ of this class, there is a theoretical set $A_{N_{i}}$, such that $\operatorname{cl}\left(A_{N_{i}}\right)=N_{i}$, $\varphi\left(N_{i}\right)=A_{N_{i}}$ and $\bigcap_{i} N_{i}=M \in E_{[T]}$.

Definition 16. The class $[T]$ with $A P_{[T]} \neq \varnothing$ will be called $J-\varphi(\bar{x})$-convex if it is convex in the classical sense [1] and for any existentially closed model $N_{i}$ of this class, there is the Jonsson set $A_{N_{i}}$, such that $\operatorname{cl}\left(A_{N_{i}}\right)=N_{i}$, 
$\varphi\left(N_{i}\right)=A_{N_{i}}$ and $\cap_{i} N_{i}=M, M \in E_{[T]} \cap A P_{[T]}, N_{i} \prec_{\Sigma_{1}} C_{[T]}$, where $A P_{[T]}$ is the set of all algebraically prime models of the class $i T]$.

The following definition defines the inner world $\left(I W_{[T]}(A)\right)$ of the model $A$ of the class $[T]$ when $A \in E_{[T]}$.

Definition 17. Let $[T] \in J \operatorname{SpV}(K)([T] \in J \operatorname{SpQV} V(K)) . I W_{[T]}(A)=\left\{A^{\prime} \in E_{[T]} \mid f\right.$ is isomorphism, $\left.f: A^{\prime} \rightarrow A, A \in E_{[T]}\right\}$ is called the inner world of the model $A$ for $[T]$.

The following definition defines the outer world $\left(O W_{[T]}(A)\right)$ of the model $A$ of the class $[T]$ when $A \in E_{[T]}$. Definition 18. $[T] \in J \operatorname{SpV}(K)([T] \in J S p Q V(K)) . O W_{[T]}(A)=\left\{B \in E_{[T]}\right.$ : there exist $\left.A^{\prime} \cong A, A^{\prime} \subseteq B\right\}$ is called the outer world of the model $A$ for $[T]$.

Just the world of the existentially closed model $A$ will be the following set

$$
W_{[T]}(A)=I W_{[T]}(A) \cup O W_{[T]}(A) .
$$

Note that the above definitions can connect two different existentially closed models in the case of a convex theory. As the following theorem is true.

Theorem 6 . Let $T$ be the perfect, strong convex Jonsson theory. Then for any models $A, B \in E_{T}$ the following is true:

1) $O W_{T}(A) \cap O W_{T}(B) \neq \emptyset$,

2) $I W_{T}(A) \cap I W_{T}(B) \neq \emptyset$.

Proof. By virtue of the perfectness of the theory $T, E_{T}=M o d T^{*}$. All existentially closed models of the theory $T$ are models of the center of the theory $T$, therefore, property 1 ) is true due to the fact that models $A$ and $B$ are existentially closed submodels of the semantic model $C$, where $C$ - semantic model of the theory $T$. Due to the strongly convexity of the theory $T$, the intersection of any two models is not empty. Condition 2) is trivial and is performed due to the joint embedding property $(J E P)$ of the theory $T$. In particular, the model $C$ satisfies these conditions due to the $T^{+}$universality of the model $C$.

Suppose $L$ is an algebraic language and $A$ is an algebra of type $L$. If we attach the elements of $A$ as constants to $L$, then the new language will be denoted by $L(A)$. Let $K$ be a class of algebras of type $L$ and $A \in K$. We say that $A$ is existentially closed in the class $K$ if every existential sentence $\psi$ in the language $L(A)$ which is true in some extention $A \subseteq B \in K$, is also true in $A$. If we restrict ourself to the positive existential sentences, then we obtain the definition of an algebraiclly closed algebra in the class $K$. Equivalently, $A$ is existentially closed in $K$, if and only if every finite set of equations and inequations with coefficients from $A$, which is solvable in some $B \in K$ containing $A$, already has a solution in $A$ itself. Similarly $A$ is algebraically closed in $K$, if and only if every finite set of equations with coefficients from $A$, which is solvable in some $B \in K$ containing $A$, already has a solution in $A$.

The question from [7] which we can formulate as "For what varieties $V$ of algebras with $A P$ is it the case that every algebra $A$ which is algebraically closed (in the sense of groups) is existentially closed?" We would like to obtain a complete characterization of such varieties.

In this work, we found the sufficient conditions to above question under additional $J E P$-property.

Theorem 7. Let $J \operatorname{Sp} V(K)$ be a Jonsson spectrum of the Jonsson variety $K$, then if $K$ is perfect Jonsson class, for any semantic model which algebraically closed of the class $[T] \in J S p(K)$. This model belongs to $E_{[T]}$ also.

Proof. Suppose the opposite. There exists a model $A \in \operatorname{Mod}([T]),[T] \in J \operatorname{Sp} V(K)$ such that $A$ is algebraically closed, but $A \notin E_{[T]}$. Then there exists a sentence $\theta=\exists \bar{x} \neg \varphi(\bar{x})$ such that any $B \in \operatorname{Mod}([T])$ such that $B \supseteq A$ and $B \models \theta$ follows that $A \not \models \theta$, then $A \models \neg \theta$, then $A \models \forall \bar{x} \varphi(\bar{x})$. Since $\forall \Delta \in[T], \Delta$-Jonsson theory, there exists $B^{\prime} \in E_{[T]}$ such that $A \rightarrow B^{\prime}, B^{\prime} \rightarrow C, C$ is a semantic model of the class [T]. If $B \in E_{[T]}$, then $B \equiv_{\forall \exists} B^{\prime}$ and the sentence $\theta$ in a particular case is a $\forall \exists$-sentence. If $B \notin E_{[T]}$, then there exists $B^{\prime \prime} \in E_{[T]}$, such that $B \rightarrow B^{\prime \prime}$ и $B^{\prime \prime} \rightarrow B^{\prime}$.

Also, for all who have an interest in the particular case of the above-considered materials, one can find out in the following resources [8-12].

\section{Acknowledgments}

This work was supported by the Science Committee of the Ministry of Education and Science of the Republic of Kazakhstan (grant AP09260237). 


\title{
References
}

1 Barwise J. Ed.Handbook of mathematical logic. Part 1, Model Theory. / J. Barwise. - M.: Nauka, 1982. 2 Мальцев А.И. Алгебраические системы / А.И. Мальцев. - М.: Наука, 1970. - 392 с.

3 Yeshkeyev A.R. Model-theoretical questions of the Jonsson spectrum / A.R. Yeshkeyev // Bulletin of the Karaganda University - Mathematics. - 2020. - Vol. 98. - No. 2. - C. 165-173. DOI: 10.31489 /2020M2/165-173

4 Ешкеев A.Р. $J S p$-косемантичность $R$-модулей / А.Р. Ешкеев, О.И. Ульбрихт // Сиб. электрон. мат. изв. - 2019. - 16. - С. 1233-1244. Doi 10.33048 / semi.2019.16.084

5 Ешкеев А.Р. $J S p$-косемантичность и $J S B$-свойство абелевых групп / А.Р. Ешкеев, О.И. Ульбрихт // Сиб. электрон. мат. изв. - 2016. - 13. - С. 861-874. Режим доступа: http://semr.math.nsc.r DOI: 10.17377/semi.2016.13.068

6 Ешкеев А.Р. Йонсоновские теории и их классы моделей: моногр. / А.Р. Ешкеев, М.Т. Касыметова. - Караганда: Изд-во КарГУ, 2016. - 370 с.

7 Forrest W. Model theory for universal classes with the amalgamation property: a study in the foundations of model theory and algebra / W. Forrest // Annals of Mathematical Logic, 1977. - 11. - P. 263-366.

8 Yeshkeyev A.R. del-cl-atomic and prime sets / A.R. Yeshkeyev, A.K. Issayeva // Bulletin of the Karaganda University. Mathematics series. - 2019. - 93. - No. 1. - P. 88-94. DOI: 10.31489/2019M1/88-94

9 Yeshkeyev A.R. The atomic definable subsets of semantic model / A.R. Yeshkeyev, N.M. Mussina, A.K. Issayeva // Bulletin of the Karaganda University. Mathematics series. - 2019. - 94. - No. 2. P. 84-91. DOI 10.31489/2019M2/84-91

10 Yeshkeyev A.R. Properties of hybrids of Jonsson theories / A.R. Yeshkeyev, N.M. Mussina // Bulletin of the Karaganda University. Mathematics series. - 2018. - 92. - No. 4. - P. 99-104. DOI: 10.31489/2018M4 /99-104

11 Yeshkeyev A.R. Companions of the fragments in the Jonsson enrichment / A.R. Yeshkeyev // Bulletin of the Karaganda University. Mathematics series. - 2017. - Vol. 85. - No. 1. - P. 41-45. DOI:10.31489/2017M1 $/ 41-45$

12 Yeshkeyev A.R. The Properties of Similarity for Jonsson's Theories and Their Models / A.R. Yeshkeyev // Bulletin of the Karaganda University. Mathematics series. - 2015. - Vol. 80. - No. 4. - P. 52-59.

\section{A.P. Ешкеев}

Академик Е.А. Бөкетов атындавъ Қараванды университеті, Қараванды, Қазақстан

\section{Йонсондық көптүрлілік және квазикөптүрлілік туралы}

\begin{abstract}
Мақалада модельдер теориясы тұрғысынан да, әмбебап алгебра тұрғысынан да жаңа зерттеу объектілері анықталды. Атап айтқанда, йонсондық көптүрлілік пен йонсондық квазикөптүрліліктің йонсондық спектрлері қарастырылған. Дөңестіліктің 3 түрінің негізгі түсініктері берілген: локальді дөңес теория, $\varphi(x)$-дөңес теория, $J-\varphi(x)$-дөңес теория. Сонымен қатар, теориялар класының ішкі және сыртқы әлемдері зерттелген. Негізгі нәтиже В.Форрестің сұрағымен байланысты, ол алгебралық тұйық көптүрліліктің экзистенциалды тұйықталуына қатысты. Мақалада авторы бұл сұраққа оң жауап беру үшін жеткілікті шартты келтірген.
\end{abstract}

Kiлm сөздер: йонсондық теория, семантикалық модель, йонсондық спектр, йонсондық көптүрлілік, йонсондық квазикөптүрлілік. 


\title{
A.P. Ешкеев
}

Карагандинский университет имени академика Е.А. Букетова, Караганда, Казахстан

\section{О йонсоновских многообразиях и квазимногообразиях}

\begin{abstract}
В статье определены новые объекты исследования, как с позиции теории моделей, так и с позиции универсальной алгебры. В частности, рассмотрены йонсоновские спектры йонсоновских многообразий и йонсоновских квазимногообразий. Даны основные понятия трех видов выпуклости: локально выпуклая теория, $\varphi(x)$-выпуклая теория, $J-\varphi(x)$-выпуклая теория. Кроме того, изучены внутренние и внешние миры модели класса теорий. Основной результат связан с вопросом У. Форреста, который относится к экзистенциальной замкнутости алгебраически замкнутого многообразия. Автором статьи приведено достаточное условие для положительного ответа на данный вопрос.
\end{abstract}

Ключевые слова: йонсоновская теория, семантическая модель, йонсоновский спектр, йонсоновское многообразие, йонсоновское квазимногообразие.

References

1 Barwise, J. (1982). Ed. Handbook of mathematical logic. Part 1, Model Theory. Moscow: Nauka.

2 Maltsev, A.I. (1970). Algebraicheskie sistemy [Algebraic systems]. Moscow: Nauka; Glavnaia redaktsiia fiziko-matematicheskoi literatury [in Russian].

3 Yeshkeyev, A. R. (2020). Model-theoretical questions of the Jonsson spectrum. Bulletin of the Karaganda University. Mathematics series, 98(2), 165-173. DOI: 10.31489/2020M2/165-173

4 Yeshkeyev, A.R., \& Ulbrikht, O.I. (2019). JSp-kosemantichnost R-modulei [JSp-cosemanticness of R-modules]. Sibirskie elektronnye matematicheskie izvestiia - Siberian Electronic Mathematical Reports, 16, 1233-1244, Doi: 10.33048/semi.2019.16.084 [in Russian].

5 Yeshkeyev, A.R., \& Ulbrikht, O.I. (2016). JSp-kosemantichnost i JSB-svoistvo abelevykh grupp [JSp-cosemanticness and JSB property of Abelian groups]. Sibirskie elektronnye matematicheskie izvestiia - Siberian Electronic Mathematical Reports, 13, 861-874 [in Russian].

6 Yeshkeyev, A.R., \& Kassymetova, M.T. (2016). Yonsonovskie teorii i ikh klassy modelei /Jonsson theories and their classes of models]. Karaganda: Izdatelstvo Karagandinskogo gosudarstennogo universiteta [in Russian].

7 Forrest W. (1970). Model theory for universal classes with the amalgamation property: a study in the foundations of model theory and algebra, Annals of Mathematical Logic.

8 Yeshkeyev, A.R., \& Issayeva, A.K. (2019). del-cl-atomic and prime sets. Bulletin of the Karaganda University. Mathematics series, 93(1), 88-94. Doi: 10.31489/2019M1/88-94

9 Yeshkeyev A.R., Mussina, N.M., \& Issayeva, A.K. (2019). The atomic definable subsets of semantic model. Bulletin of the Karaganda University. Mathematics series, 94(2), 84-91. Doi 10.31489/2019M2/84-91

10 Yeshkeyev, A.R., \& Musina, N.M. (2018). Properties of hybrids of Jonsson theories. Bulletin of the Karaganda University. Mathematics series, 92(4), 99-104. Doi: 10.31489/2018M4/99-104

11 Yeshkeyev, A.R. (2017). Companions of the fragments in the Jonsson enrichment. Bulletin of the Karaganda University. Mathematics series, 85(1), 41-45. Doi: 10.31489/2017M1/41-45

12 Yeshkeyev, A.R. (2015). The Properties of Similarity for Jonsson's Theories and Their Models. Bulletin of the Karaganda University. Mathematics series, 80(4), 52-59. 